\title{
Correlation between Inflammation and Fibrinolysis in Hypertensive Centrally Obese Subjects: A study on C-Reactive Protein, Plasminogen Activator Inhibitor-1 and Thrombin Activatable Fibrinolysis Inhibitor
}

\author{
Yati Sumiyati ${ }^{1 *}$, Syakib Bakri' and Mansyur Arif ${ }^{1}$ \\ ${ }^{1}$ Post Graduate Program in Clinical Biochemistry, Hasanuddin University, \\ JI. Perintis Kemerdekaan Km.10. Makassar, Indonesia \\ ${ }^{\star}$ Correspondence: Prodia Clinical Laboratory, JI. Kramat Raya 150, Jakarta, Indonesia \\ e-mail: yati.sumiyati@yahoo.com
}

\section{Abstract}

B

ACKGROUND: Hypertension and central obesity are risk factors of cardiovascular disease. Epidemiology studies have shown that these two conditions are closely linked and often occur simultaneously. Inflammation is an underlying pathomechanism in hypertension and obesity. Vascular inflammation is related to coagulation pathway, whereby high level of inflammation increases the risk of atherothrombosis event. The aim of this study was to investigate the correlation between inflammation and fibrinolysis in hypertensive centrally obese subjects compared with hypertensive non obese subjects.

METHODS: This was a cross sectional study conducted in October 2009-June 2010 involving 53 eligible subjects according to the following criteria: men or women aged 30-65 years, had neither diabetes (FPG $<126 \mathrm{mg} / \mathrm{dL}$ and or OGTT $<200 \mathrm{mg} / \mathrm{dL}$ ) nor CKD (eGFR $\geq 60 \mathrm{~mL} /$ minutes). All subjects were not in an acute inflammation state, had no unspecific infection (hs-CRP $\leq 10 \mathrm{mg} / \mathrm{L}$ ), or taking anti-inflammation or anti-hypertensive medication.

RESULTS: In this study we found that the levels of hs-CRP (2.636 mg/L vs $1.024 \mathrm{mg} / \mathrm{L}, \mathrm{p}=0.007)$, PAI-1

\section{Abstrak}

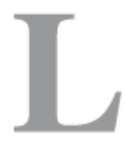

ATAR BELAKANG: Hipertensi dan obesitas merupakan faktor risiko independen terhadap penyakit kardiovaskular. Penelitian epidemiologi menunjukkan bahwa hipertensi dan obesitas sering terjadi secara bersamaan dan akan semakin meningkatkan risiko kardiovaskular. Inflamasi merupakan salah satu patomekanisme yang mendasari komplikasi kardiovaskular pada hipertensi maupun obesitas. Inflamasi vaskular berhubungan dengan jalur koagulasi, dimana status inflamasi yang tinggi dapat meningkatkan risiko kejadian aterotrombosis. Tujuan penelitian ini adalah untuk mengetahui korelasi antara inflamasi dengan fibrinolisis pada subyek hipertensi obes sentral dan hipertensi non-obes sentral.

METODE: Penelitian menggunakan metode potong lintang, dilakukan mulai Oktober 2009-Juni 2010 pada 53 subyek penelitian yang memenuhi kriteria inklusi yaitu pria atau wanita berusia 30-65 tahun, tidak menderita diabetes (glukosa darah puasa $<126 \mathrm{mg} / \mathrm{dL}$ dan/atau tes toleransi glukosa oral $<200 \mathrm{mg} / \mathrm{dL}$, tidak mengalami penyakit ginjal kronis (estimasi laju filtrasi glomerulus $\geq$ $60 \mathrm{~mL} / \mathrm{menit}$ ), tidak mengalami inflamasi akut atau infeksi (hs-CRP $\leq 10 \mathrm{mg} / \mathrm{L}$ ) dan tidak mengkonsumsi obat antihipertensi atau anti-inflamasi. 
(43.58 $\mathrm{ng} / \mathrm{mL}$ vs $28.43 \mathrm{ng} / \mathrm{mL}, \mathrm{p}=0.089)$ and TAFI (12.73 $\mathrm{ng} / \mathrm{mL}$ vs $12.19 \mathrm{ng} / \mathrm{mL}, \mathrm{p}=0.479$ ) were respectively higher in hypertensive subjects with central obesity than in hypertensive subjects with no central obesity. In hypertensive centrally obese subjects there was significant positive correlation between hs-CRP and PAI-1 $(r=0.491$, $\mathrm{p}=0.001)$ and TAFI $(\mathrm{r}=0.312, \mathrm{p}=0.039)$, meanwhile in hypertensive non-obese subjects significant correlation was found only between hs-CRP and TAFI ( $r=0.929$, $p$ $=0.003$ ).

CONCLUSIONS: Obesity in hypertensive subjects has higher inflammation state that is correlated with fibrinolysis disruption.

KEYWORDS: hypertension, obesity, hs-CRP, PAI-1, TAFI

Indones Biomed J 2012; 4 (3): 151-156
HASIL: Penelitian ini menunjukkan bahwa rerata konsentrasi hs-CRP (2.636 vs $1.024 \mathrm{mg} / \mathrm{L}, \mathrm{p}=0.007$ ), PAI-1 (43.58 vs $28.43 \mathrm{ng} / \mathrm{mL}, \mathrm{p}=0.089)$ dan TAFI (12.73 vs $12.19 \mathrm{ng} / \mathrm{mL}, \mathrm{p}=0.479$ ) lebih tinggi pada subyek hipertensi obes sentral dibandingkan subyek hipertensi non-obes sentral. Pada subyek hipertensi obes sentral didapatkan hubungan positif yang bermakna antara hsCRP dengan PAI-1 $(r=0.491, \mathrm{p}=0.001)$ dan TAFI $(\mathrm{r}=$ $0.312, p=0.039$ ), sementara pada subyek hipertensi nonobes sentral hanya ditemukan hubungan yang bermakna antara hs-CRP dengan TAFI $(r=0.929, p=0.003)$.

KESIMPULAN: Obesitas pada subyek hipertensi akan lebih meningkatkan status pro-inflamasi yang berkorelasi dengan peningkatan penghambatan fibrinolisis.

KATA KUNCI: hipertensi, obesitas, hs-CRP, PAI-1, TAFI

Indones Biomed J 2012; 4 (3): 151-156

\section{Introduction}

Hypertension or increased level of blood pressure causes increased risks of cardiovascular events, but medication can significantly decrease cardiovascular morbidity and mortality. High blood pressure affects approximately 20$30 \%$ of the adult population and it has been predicted that the prevalence will increase to $60 \%$ in 2025 . Cardioreno-cerebrovascular diseases are manifestations due to hypertension $(1,2)$.

There is a reciprocal relationship between vascular inflammation and hypertension. Several longitudinal studies have shown that subjects with high level of high sensitivity C-Reactive Protein (hs-CRP) - as a marker of low-grade inflammation, have a greater risk of developing hypertension compared with subjects with lower level of hs-CRP. On the other hand, hypertensive subjects indicated a higher level of hs-CRP (3).

Obesity is a condition characterized by accumulation of execessive fat in the adipose tissues with the consequences of developing hyperinsulinemia, diabetes, and hypertension (4). The Reduction of Atherothrombosis for Continued Health registry, an epidemiological research on subjects with or at high risk of atherothrombotic condition which involved 44 countries showed a high prevalence of overweight $(39.8 \%)$, obesity $(26.6 \%)$ and morbid obesity $(3.6 \%)(5)$. Obesity is known as a lowgrade inflammatory condition which is characterized by the increase of pro-inflammatory cytokines and acute phase proteins. In obesity, the adipose cells are inflammed -an effect of macrophage infiltration, and inflammatory cytokines are produced in high level (sick fat cells). This mechanism results in the pro-atherosclerotic properties of sick fat cells $(5,6)$.

At all levels of blood pressure, additional cardiovascular risk factors increase the risk of cardiovascular events; thus hypertensive subjects with obesity have a higher cardiovascular risk than non-obese hypertensive subjects. Cardiovascular events, in this case as atherothrombotic, was associated with an increase in low-grade inflammatory status. It was postulated that obese hypertensive subjects would have higher low-grade inflammatory markers which would affect athero-thrombotic process, as compared with non-obese hypertensive subjects (7).

Atherothrombosis is a condition in which atherosclerotic plaque ruptures following a thrombotic event leading to the blockage of blood vessel. This process involves some mechanisms such as lipid deposition, inflammation and thrombus formation. Many biological substances are related to inflammation that shifts the hemostatic mechanisms in favor of 
thrombosis. Atherothrombosis is characterized by an increase in pro-inflammatory status, platelet activation, and hypercoagulable state. Elevated expression of inflammatory mediators such as IL-6 and CRP have shown correlation with an increased risk of atherothrombotic events $(8,9)$.

Previous studies showed that high sensitivity C-Reactive Protein (hs-CRP) is the most sensitive acute phase reactant in which the level will increase rapidly as a response to inflammation (10). Elevated production of Plasminogen Activator Inhibitor-1 (PAI-1) by adipose cells as a result of high levels of CRP are associated with increased fibrinogen level and decreased fibrinolytic capacity (11). It was known that atherothrombotic events can be affected by Thrombin-activatable fibrinolysis inhibitor (TAFI), a protein that can lead to downregulation of fibrinolysis (12). This study was conducted to determine the correlation between inflammation and fibrinolysis in hypertensive centrally obese subjects and hypertensive non-obese subjects.

\section{Methods}

\section{Study Design}

This was an observational study with cross-sectional design. The study subjects were recruited from Jakarta population in the period of October 2009-June 2010.

\section{Subjects}

Eligible subjects were recruited based on inclusion criteria as follows: men or women aged 30-65 with hypertension as defined by JNC-7, 2003. Subjects had neither diabetes (Fasting Plasma Glucose $<126 \mathrm{mg} / \mathrm{dL}$ and or Oral Glucose Tolerance Test $<200 \mathrm{mg} / \mathrm{dL}$ ) nor Chronic Kidney Disease (estimated Glomerulus Filtration Rate $\geq 60 \mathrm{~mL}$ /minutes). All subjects not in an acute inflammation state or having unspecific infection (hs-CRP $\leq 10 \mathrm{mg} / \mathrm{L}$ ) or taking antiinflammation or anti-hypertensive medication.

\section{Biochemical Analysis}

Blood pressure was measured by using mercury sphygmomanometer. Subjects with a systolic blood pressure (SBP) of $\geq 140 \mathrm{mmHg}$ or a diastolic blood pressure of $\geq 90 \mathrm{mmHg}$ were considered as hypertensive. Waist circumference (WC) was measured according to the procedure of NHANES III anthropometric measurements of waist between lower rib and crista iliaca, using nonelastic tape. Subjects with $W C \geq 90 \mathrm{~cm}$ for men and $W C \geq 80$ $\mathrm{cm}$ for women were considered as central obesity. Levels of glucose, creatinine, AST and ALT were determined by Siemens ADVIA 1800 auto analyzer. hs-CRP level was measured by the method of chemilluminescence immunoassay while PAI-1 and TAFI levels were measured using enzyme-linked immunosorbent assay method.

\section{Data Analysis}

Statistical analysis was performed with SPSS for Windows version 13.0 (USA, SPSS Inc) using descriptive analysis, Kolmogorov-Smirnov distribution test, Mann-Whitney test and Spearman correlation. Hypotheses were tested at a significance level of 0.05 .

\section{Results}

Mean of hs-CRPlevel was $2.415 \mathrm{mg} / \mathrm{L}$ in all study subjects, which indicated intermediate risk of cardiovascular disease. Kolmogorov-Smirnov test showed that age, BMI, WC, SBP, fasting glucose, OGTT, AST, creatinine, eGFR, Triglycerides, HDL-c, LDL-c and TAFI had a normal distribution, while DBP, ALT, hs-CRP and PAI-1 had an abnormal distribution. Thus, non-parametric tests were used for data analysis.

Table 2 shows a significant difference of hs-CRP $(p=0.007)$ in which mean of hs-CRP level was higher in hypertensive central obese subjects compared with hypertensive non-obese subjects $(2.636 \mathrm{mg} / \mathrm{L}$ vs 1.024 $\mathrm{mg} / \mathrm{L})$.

Age and dyslipidemia status are independent risk factors for cardiovascular events that can affect on the research variables. However, the Spearman correlation test showed no correlation of age, triglycerides, HDL-C and LDL-C with hs-CRP, PAI-1 and TAFI levels (data not shown).

Table 3 shows significant correlation between hs-CRP and PAI-1 in hypertensive centrally obese subjects ( $\mathrm{rs}=$ $0.491, \mathrm{p}=0.001$ ), while positive significant correlation was found between hs-CRP and TAFI in hypertensive centrally obese subjects $(\mathrm{rs}=0.312, \mathrm{p}=0.039)$ and hypertensive non-obese subjects $(r s=0.929, p=0.003)$. 
Table 1. Clinical and biochemical characteristics of subjects

\begin{tabular}{lccc}
\hline Variable (unit) & N & Range & Mean \pm SD \\
\hline Clinical & & & \\
Age (year) & 53 & $31-63$ & $50.3 \pm 8.34$ \\
BMI (kg/m²) & 53 & $21-35$ & $27.3 \pm 3.55$ \\
WC (Cm) & 53 & $73-120$ & $92.4 \pm 9.02$ \\
DBP (mmHg) & 53 & $75-105$ & $91.3 \pm 5.98$ \\
SBP (mmHg) & 53 & $125-170$ & $142.2 \pm 10.93$ \\
Biochemical & & & \\
Triglyceride (mg/dL) & 53 & $54-228$ & $124.1 \pm 44.56$ \\
HDL-c (mg/dL) & 53 & $32-86$ & $49.9 \pm 10.05$ \\
LDL-c $(\mathrm{mg} / \mathrm{dL})$ & 53 & $60-234$ & $135.3 \pm 31.65$ \\
PAl-1 $(\mathrm{ng} / \mathrm{mL})$ & 52 & $6.29-116.8$ & $41.25 \pm 28.344$ \\
TAFI $(\mathrm{ng} / \mathrm{mL})$ & 53 & $7.3-17.3$ & $12.64 \pm 2.520$ \\
& & & \\
\hline
\end{tabular}

BMI=Body Mass Index; DBP=Diastolic Blood Pressure; HDL-C=High Density Lipoprotein-cholesterol; LDL$\mathrm{C}=$ Low Density Lipoprotein-cholesterol; PAI-1=Plasminogen Activator Inhibitor-1; SBP=Systolic Blood Pressure; TAFI=Thrombin Activatable Fibrinolysis Inhibitor; WC=Waist Circumference.

Table 2. Two different test groups for research variable towards hypertension and central obesity status

\begin{tabular}{lccccc}
\hline Variable (unit) & \multicolumn{2}{c}{ Hypertensive Centrally Obese } & \multicolumn{2}{c}{ Hypertensive Non-Obese } \\
& $\mathbf{N}$ & Mean \pm SD & N & Mean \pm SD \\
\hline hs-CRP $(\mathrm{mg} / \mathrm{L})$ & 44 & $2.636 \pm 2.4707$ & 7 & $1.024 \pm 1.5021$ & 0.007 \\
PAl-1 $(\mathrm{ng} / \mathrm{mL})$ & 44 & $43.58 \pm 28.121$ & 8 & $28.43 \pm 27.805$ & 0.089 \\
TAFI $(\mathrm{ng} / \mathrm{mL})$ & 45 & $12.73 \pm 2.535$ & 8 & $12.19 \pm 2.553$ & 0.479 \\
\hline
\end{tabular}

hs-CRP=high sensitivity C-Reactive Protein, PAl-1=Plasminogen Activator Inhibitor-1, TAFI=Thrombin Activatable Fibrinolysis Inhibitor; $\mathrm{SD}=$ Standard Deviation.

Table 3. Correlation of hs-CRP with PAI-1 and TAFI in hypertensive centrally obese subjects and hypertensive non-obese subjects

\begin{tabular}{cccccccc}
\hline Parameter & \multicolumn{9}{c}{ Hypertensive Centrally Obese Subjects } & \multicolumn{3}{c}{ Hypertensive Non-Obese Subjects } \\
& $\mathbf{N}$ & $\mathbf{r}_{\mathbf{s}}$ & $\mathbf{p}$ & $\mathbf{N}$ & $\mathbf{r}_{\mathbf{s}}$ & $\mathbf{p}$ \\
\hline hs-CRP & & & & & & \\
PAI-1 & 43 & 0.491 & 0.001 & 7 & 0.321 & 0.482 \\
TAFI & 44 & 0.312 & 0.039 & 7 & 0.929 & 0.003 \\
\hline
\end{tabular}




\section{Discussion}

Hypertension is a risk factor for atherosclerosis where one of the underlying mechanisms occurs through inflammatory pathways. Central obesity is another risk factor which has been reported to play a role in cardiovascular events through endothelial dysfunction, hyperinsulinemia, diabetes or hypertension. Hypertension and central obesity are two conditions associated with inflammation. These two conditions are closely linked and can increase the total (global) cardiovascular risks that give rise to more severe impacts, such as the state of the metabolic syndrome (mets) (4).

Previous studies have shown the association of increased prevalence of hypertension with increased body mass index (13). Blood pressure levels are intimately associated with central obesity and insulin resistance. On the other hand, hyperglycemia, hyperlipidemia, and hypertension are conditions commonly coexist in obese individuals (14). Multi-Ethnic Study of Atherosclerosis indicated that out of 3,543 non-hypertensive subjects at baseline, 714 subjects would develop hypertension. BMI and WC are major predictors of the incidence of hypertension (15).

There was a significant difference found between hypertensive centrally obese subjects and hypertensive non-obese subject in terms of the levels of hs-CRP ( $\mathrm{p}=$ 0.007). This result is consistent with that of the MONICA (Multinational Monitoring of trends and determinants in cardiovascular disease) study which found difference level of hs-CRP to BMI and found significant correlation of hs-CRP with SBP and BMI (16). hs-CRP is a marker of systemic inflammation and strongly associated with Mets and its components. A study conducted by den Engelsen, et al (2012) found that hs-CRP median increased with increased number of Mets components. Adipose tissue is known as endocrine organ which secretes cytokines that stimulate the formation of hs-CRP in the liver. Adipose tissue itself can secrete hs-CRP whereby its levels will increase significantly (17).

Hypertension increases inflammatory status through the expression of several mediators including leukocyte adhesion molecules, chemokines, specific growth factors, heat shock proteins, endothelin-1 and angiotensin; hypertension associated with hemostatic abnormalities, which play important role in the development of atherothrombotic events. Although in the early stage, hypertension can lead to blood vessel wall injury and activate the coagulation system. Endothelial dysfunction stimulates the platelet and coagulation systems, especially due to impaired fibrinolysis activity, which supports the formation of marginal and intramural fibrin deposits and the development of atherosclerotic plaques (18).

Central obesity is associated with chronic low grade inflammation characterized by elevated proinflammatory cytokines such as TNF- $\alpha$, IL-6, IL-1 $\beta$ and acute phase proteins such as CRP, which increase risk for cardiovascular disease (4). The correlation between obesity and inflammation is possibly related with endoplasmic reticulum stress due to excess intake of nutrients. Storage of excess nutrients requires the synthesis of proteins that increase the formation of free radicals and initiate inflammatory process. The correlation between obesity and thrombosis may be due to conjugation of leptin, a cytokine produced by adipose tissue, whereby its receptors are expressed on platelets and potentiation platelet aggregation process (19).

Fibrinolysis and coagulation systems have opposite functions, where the regulation of enzymes in the two cascades is very important in preventing excessive thrombus formation. A correlation was shown between coagulation pathways and inflammation in which the interaction between these two systems are carried out by thrombin and TAFI (20). The results of this study showed a significant correlation between hs-CRP and PAI-1 $(\mathrm{r}=0.312, \mathrm{p}=0.039)$ and TAFI $(\mathrm{r}=0.491, \mathrm{r}=0.001)$, respectively, which indicated a correlation between inflammatory and the coagulation process. A study conducted by Gutierrez-Missin A, et al. (2011) showed that hypertension was associated with endothelial dysfunction, platelet activation, increased thrombin formation and inhibition of fibrinolysis processes. Currently a growing new concept on coagulation is gaining wider acceptance, which states coagulation process is controlled by the levels and kinetics of coagulation proteins, as opposed to the previously accepted concept that states that coagulation process is controlled by the cellular components (21).

The role of pro-inflammatory cytokines in the coagulation pathway may be linked with the induction of endothelial cells that decreases the expression trombomodulin, increased expression of tissue factor and adhesion molecules to initiate hemostasis as to injury (21). TAFI is also known as procarboxypeptidase B; plasma zymogen that acts as potent inhibitor of fibrinolysis system. It has been hypothesized that the increase of TAFI activity is associated with thrombus formation. Fibrinolysis activity is modulated by the balance between fibrinolysis activators such as IPA with the fibrinolysis inhibitor such as PAI-1 (22). Activation of the coagulation system induces the formation of thrombin which has a role 
as physiological activator for TAFI and its transformation into an active form. TAFIa possesses carboxypeptidase that will cleavage the lizyne residue at the $\mathrm{C}$-terminal. This reaction inhibits the formation of complex plasma fibrinplasminogen-plasmin resulting in increased production of plasmin thus low activity of fibrinolysis (18).

Untreated hypertensive subjects usually have a hypercoagulable state with an increase in serum levels of TAFI. Potential role of TAFI activity as a risk factor for ischemic heart disease has been shown in PRIME (The Prospective Epidemiological Study of Myocardial Infarction) study where all subjects with high levels of TAFI showed the development of ischemic heart disease over 5 years of monitor. Jastrzębska, et al. stated that the hypercoagulable state in hypertension might be caused by tissue plasminogen activator and converting enzyme gene polymorphism that affects fibrinolysis modification (18).

\section{Conclusion}

From this study we concluded that obesity in hypertensive subjects increases inflammation status which is correlated with elevated fibrinolysis inhibitor status.

\section{Acknowledgements:}

We are grateful to PT. Prodia Widyahusada for facilitating in the pocesses of this research.

\section{References:}

1. Chobanian AV, Bakris GL, Black HR, Cushman WC, Green LA, Izzo JL, et al. Seventh Report Of The Joint National Committee On Prevention, Detection, Evaluation, And Treatment Of High Blood Pressure. Hypertension 2003; 42: 1206-52.

2. Org E, Veldre G, Viigimaa M, Juhanson P, Putku M, Rosenberg $M$, et al. HYPEST study: profile of hypertensive patients in Estonia. BMC Cardiovascular Disorders 2011; 11: 55.

3. Bautista LE, Lopez-Jaramillo P, Vera LM, Casas JP, Otero AP, Guaracao Al. Is C-Reactive Protein an Independent Risk Factor for Essential Hypertension. J Hypertens 2001; 19: 857-66.

4. Grundy, SM. Metabolic syndrome: connecting and reconciling cardiovascular and diabetes worlds. J Am Coll Cardiol 2006; 47: 1093-100.
5. Bhatt DL, Steg PG, Ohman EM, Hirsch AT, Ikeda Y, Mas J, et al. International Prevalence, Recognition, and Treatment of Cardiovascular Risk Factors in Outpatients With Atherothrombosis. JAMA 2006; 295: 180-9.

6. Wellen KE and Hotamisligil GS. Inflammation, stress and diabetes. J Clin Invest. 2005; 115: 1111-9.

7. Mancia G, De Backer G, Dominiczak A, Cifkova R, Fagard $R$, Germanò $G$, et al. Guidelines for the management of arterial hypertension: The Task Force for the Management of Arterial Hypertension of the European Society of Hypertension (ESH) and of the European Society of Cardiology (ESC). Eur Heart J 2007; 28; 1462536.

8. Esmon CT. Crosstalk between inflammation and thrombosis. Maturitas 2004; 61: 122-31.

9. Tedgui A. The role of inflammation in atherothrombosis: implications for clinical practice. Vasc Med 2005; 10: 4553.

10. Verma S., Buchanan MR. and Anderson TJ. Endothelial Function Testing as a Biomarker of Vascular Disease. Circulation 2003; 108: 2054-9.

11. Grant PJ and Ajjan R. Coagulation and Atherothrombotic Disease. Atherosclerosis 2006; 186: 240-59.

12. Bouma BN and Meijers JCM. Thrombin-activatable fibrinolysis inhibitor (TAFI, plasma procarboxypeptidase $B$, procarboxypeptidase R, procarboxypeptidase U). J Thromb Haemost 2003; 1: 1566-74.

13. Gutierrez-Missin A Sanchez-Santos MT, Banegas JR, Zunzunegui MV, Castell MV and Otero. Prevalence and incidence of hypertension in a population cohort of people aged 65 years or older in spain. J Hypertens 2011; 29: 1863-70.

13. Yanai $\mathrm{H}$, Tomono $\mathrm{Y}$, Ito $\mathrm{K}$, Furutani $\mathrm{N}$, Yoshida $\mathrm{H}$ and Tada $\mathrm{N}$. The underlying mechanisms for development of hypertension in the metabolic syndrome. Nutr J 2008; 7 : 1-10.

14. Engstrom G. Inflammation, obesity and risk of hypertension: shared pathways or independent risk factors?. J Hum Hypertens 2011; 25: 71-2.

15. Koenig W, Khuseyinova N, Baumert $\mathrm{J}$ and Meisinger $\mathrm{C}$. Prospective Study of High-Sensitivity C-Reactive Protein as a Determinant of Mortality: Results from the MONICA/ KORA Augsburg Cohort Study, 1984-98. Clin Chem 2008; 54: 335-42.

16. Den Engelsen C, Koekkoek PS, Gorter KJ, van den Donk M, Salome PL, Rutten GE. High-sensitivity C-reactive protein to detect metabolic syndrome in a centrally obese population: a cross-sectional analysis. Cardiovasc Diabetol 2012; 11: 1-14.

17. Malyszke $\mathrm{J}$ and Tymcio $\mathrm{J}$. Thrombin activatable fibrinolysis inhibitor and other hemostatic parameters in patients with essential arterial hypertension. Polskie Archiwum Medycyny Wewnetrznej 2008; 118: 36-40.

18. Samocha-Bonet D, Justo D, Rogowski O Saar N, Abu-Abeid $\mathrm{S}$, Shenkerman G, et al. Platelet Counts and Platelet Activation Markers in Obese Subjects. Mediators Inflamm, Article ID 834153, 6 pages (eJournal).

19. Medcalf RL. Fibrinolysis, inflammation, and regulation of the plasminogen activating system. J Thromb Haemost 2007; 5: $132-42$.

20. Hoffman M and Monroe III DM. A Cell-based Model of Hemostasis. Thromb Haemost 2001; 85: 958-65.

21. Monasterioa J, Bermúdeza $P$, Quirogaa $D$, Franciscoa $E$, Menesesa B, Montanerb J. Plasma Thrombin-Activatable Fibrinolytic Inhibitor (TAFI) among Healthy Subjects and Patients with Vascular Diseases: A Validation Study. Pathophysiol Haemost Thromb 2004; 33: 382-7. 